\title{
Photovoltaic Module with Uniform Water Flow on Top Surface
}

\author{
M. S. Govardhanan $\mathbb{D}^{1},{ }^{1}$ G. Kumaraguruparan, ${ }^{2}$ M. Kameswari, ${ }^{3}$ R. Saravanan, ${ }^{4}$ M. Vivar, ${ }^{5}$ \\ and K. Srithar ${ }^{1}$ \\ ${ }^{1}$ Department of Mechanical Engineering, Thiagarajar College of Engineering, Madurai 625 015, India \\ ${ }^{2}$ Department of Mechantronics Engineering, Thiagarajar College of Engineering, Madurai 625 015, India \\ ${ }^{3}$ Department of Mathematics, Thiagarajar College of Engineering, Madurai 625 015, India \\ ${ }^{4}$ Department of Mechanical Engineering, College of Engineering-Guindy Campus, Anna University, Chennai 600 025, India \\ ${ }^{5}$ Grupo IDEA, Universidad de Jaén, Jaén 23071, Spain
}

Correspondence should be addressed to M. S. Govardhanan; govardhanans07@gmail.com

Received 23 February 2020; Revised 3 June 2020; Accepted 19 June 2020; Published 10 July 2020

Academic Editor: Alberto Álvarez-Gallegos

Copyright (c) 2020 M. S. Govardhanan et al. This is an open access article distributed under the Creative Commons Attribution License, which permits unrestricted use, distribution, and reproduction in any medium, provided the original work is properly cited.

Though the solar photovoltaic (PV) module is used for power production, it usually works at high temperatures, decreasing its efficiency and therefore its output. So if an effective cooling method is to be implemented, it would reduce the heat from the solar PV module and increase its power production. Significant research in water cooling on both top and bottom surfaces of the PV module widen the scope for uniform cooling with constant module temperature throughout at any instant. In this work, uniform flow is maintained by means of overflow water from a tank fitted on the top of the PV module. Experiments were carried out with and without cooling. Performance parameters in terms of power output and efficiency have been presented for the PV module without cooling and cooling with three different mass flow rates. The results show that there is a significant rise in efficiency of the PV module by reducing its temperature. An accelerated output power of $23 \mathrm{~W}$ has been observed for a higher mass flow rate of $5.3 \mathrm{~kg} / \mathrm{min}$ which is $15 \%$ higher than the photovoltaic module operating without cooling. Results were compared with previous researchers' work and found to be a good enhancement. Theoretical results agree well with experiments.

\section{Introduction}

Photovoltaic module operating temperature, ambient conditions, band gap of the semiconductor, solar irradiation, and module materials are the key factors affecting its performance. During operations, only $15-20 \%$ of incident solar radiation is trapped for electricity, and the remaining is rejected as heat. Cooling of the PV panel would provide a good solution to this problem if it could be implemented efficiently and at reasonable cost. Air, water, refrigerant, and phase-change materials are the most common cooling mediums used so far. Research work was carried out on cooling on both the top surface and the bottom surface of the PV module using different fluids like air, water, and water mixed with nanofluids.

1.1. Bottom Cooling. Rahman et al. [1] discussed various parameters like dust, humidity, temperature, and irradiation intensity which are the influencing parameters in the efficiency of the PV module. The authors used finned and tube-type heat exchangers on the back side of the PV module. Results showed that efficiency of the PV module is directly proportional to the cooling water flow rate and reduction in module temperature and inversely proportional to the reduction in humidity and dust accumulations. Results were compared between a PV module with cooling and one without cooling for different irradiance. It was found that the module efficiency decreases $0.06 \%$ for every $1^{\circ} \mathrm{C}$ rise in module temperature. Due to the effect of cooling, the output power increased to $8.04 \mathrm{~W}$ and efficiency increased to $1.23 \%$.

Bahaidarah et al. [2] developed a numerical model to predict the effect of electrical and thermal parameters on performance of the PV module. An experimental study on performance of the PV module by means of bottom cooling was also conducted. The numerical model results were found 
to be in good agreement with experimental data. The effect of mass flow rate was studied with module temperature and found that the increase in mass flow rate reduces the temperature rise. The active water cooling systems reduce surface temperature of the module by $20 \%$ with an increase in PV efficiency by $9 \%$.

Chandrasekhar et al. [3] experimentally investigated the electrical and thermal performances of a PV module with cooling system. The cooling system of the PV module was a cotton wick structure-like circular ring shape placed at the bottom of the module. The free end of the cotton wick was dipped with three different types of fluid in a reservoir (water, $\mathrm{Al}_{2} \mathrm{O}_{3}$ /water nanofluid, $\mathrm{CuO} /$ water nanofluid). By comparison, the wick structure with water was more efficient in cooling the module than the other two. The maximum power of $47.5 \mathrm{~W}$ was obtained using the wick structure with water, and the module temperature was reduced to $45^{\circ} \mathrm{C}$.

Chaniotakis [4] designed a hybrid PV/T solar system where both water and air were used as cooling agents. In the air-cooled system, the air was allowed to pass through the gap between the absorber plate and insulation at the bottom of the PV module. In the water-cooled system, a heat exchanger was attached to the bottom of the module and water flows inside the heat exchanger. On comparison of both systems, the water-based cooling system was found to boost the solar cells' performance at a higher trend compared with the air-based cooling system. The Air-cooled system has an advantage in that it is cheaper than the water-cooled system.

Ceylan et al. [5] fabricated a bottom-cooling system for the PV module with a temperature-controlled solar collector. A spiral heat exchanger was placed at the bottom of the PV module for cooling, and the experiments were performed in laboratory conditions. A temperature sensor with a solenoid valve was employed to activate the cooling system. The module temperature has been reduced from $55^{\circ} \mathrm{C}$ to $45^{\circ} \mathrm{C}$. The module efficiency has increased from $10 \%$ to $13 \%$ due to reduction in temperatures.

HaiAlami [6] examined the effect of evaporative cooling on efficiency of PV modules. This method involved incorporating a clay layer at the bottom of the PV module with a gap in between. A thin film of water flows through the gap and reduces the module temperature with evaporative cooling. The thickness of the clay layer was subjected to investigation and the variations in thickness as $2 \mathrm{~mm}, 4 \mathrm{~mm}$, and $6 \mathrm{~mm}$. The thickness $2 \mathrm{~mm}$ was found to be more efficient in recovering heat from the module. The PV module with the cooling system produced a maximum output power of $19.1 \%$ more than the module without cooling.

Performance prediction on PV module efficiency using jet impingement cooling at the bottom of the PV panel was carried out by Bahaidarah [7]. The study reveals that by employing jet cooling, the net power improved up to $49.6 \%$ with a conversion efficiency of $82.6 \%$. Optimum parameters were also determined using simulation analysis.

1.2. Top Cooling. Moharram et al. [8] presented an experimental and numerical study on cooling of the PV cell using water spraying on the top surface of the PV module. Water was sprayed on the top of the PV module using pumped water from a tank. The results reveal that maximum power was yielded from the module. It also concludes that it is possible to cool and clean the PV panels using the proposed cooling system in hot and dusty regions.

Bahaidarah et al. [9] highlighted the need for uniform cooling of PV panels by discussing the causes and effect of nonuniformity in PV systems. This work analysed the effect of uniform cooling and nonuniform cooling on $\mathrm{p}-\mathrm{V}$ module performance. The cooling techniques selected for nonuniform cooling were a conventional rectangular heat exchanger and for uniform cooling, jet impingement at the back surface. The results showed that the uniform cooling had increased efficiency and a low module temperature than the nonuniform cooling.

Hosseini et al. [10] reduced the PV module surface temperature and reflection losses through a thin-film waterflow cooling system on the top surface using a tube with silt at the top. The water collected at the bottom end passed through the finned tube heat exchanger. It was found that the temperature difference between the top and bottom sides of the PV module was almost $1.5^{\circ} \mathrm{C}$. The experimental results showed that there is a significant reduction in module temperature due to the flow of the water film.

Abdolzadeh and Ameri [11] examined the performance of a $225 \mathrm{~W}$ PV module with spraying water on the top surface. The effect of spraying water was investigated with module efficiency, module temperature, and pump flow rate. It showed that a higher pump flow rate was required in the middle hours since the temperature rise was much higher. The system with water spraying achieved $12.5 \%$ increase in module efficiency.

Shan et al. [12] stimulated the dynamic performance of the PV module with different fluid flow configurations. There were five configurations used in this analysis: without fluid flow (conventional), fluid flow on the top, fluid flow at the bottom, simultaneous fluid flow on both top and bottom, and fluid flow at the bottom and on the top in series mode. On analysing the results, the fluid flowing on the top and bottom in series mode produced higher temperature difference compared with the conventional PV module.

An experimental setup was elaborated by Nizetic et al. [13] to investigate the water spray cooling effect on both sides of the PV panel. The total power output increased to a maximum of $16.3 \%$. The module temperature was reduced to a minimum of $24^{\circ} \mathrm{C}$.

1.3. Problem Identification. It is inferred from the literature survey that when cooling using both water and air at the bottom of a solar panel $[1,2,3]$, water is found to be more efficient in terms of electrical efficiency of the PV module by reduction in temperature. Top cooling with water [8-13] augmented the cooling performance compared to bottom cooling. With the water supply on the top surface of the panel by means of a nozzle $[8,9]$, cooling of the solar panel with capillarity action [3] widens the scope of uniform flow of water on the top surface of the PV module to reduce the temperature. Also, previous authors showed that top flow cooling has an additional reduction in temperature due to water evaporation by direct contact with solar irradiation compared to bottom flow cooling. But even though a jet of water was supplied by means of a pump 
through nozzles in the pipe, nonuniform flow and uneven wetness of the liquid were observed. This causes poor convection heat transfer.

1.4. Research Gap. The literature enlightens that if effort is placed to make the water flow uniform on the top surface, then the module temperature can be reduced significantly. In this present work to ensure uniform flow, saline water is filled into an overflow tank fixed on the top surface of the PV module. Once the saline water is completely filled into the overflow tank, the excess water emerging out is uniformly flown over the surface of the PV module. This ensures all the areas of the PV module are in perfect contact with water which augments the reduction in module temperature and thereby electrical efficiency.

1.5. Scope and Objective. In this proposed work, the water flow is made uniform on the top surface of the photovoltaic module by means of overflow water from a tank. The water flow is a closed circuit which contains a submergible pump, a storage tank, and the intermediate tank. A valve controls the flow rate of the water.

The objective of the present work is to analyse the performance of the cooling effect for different mass flow rates. Also, the effect of temperature on electrical efficiency is carried out. The output of the PV module is to be determined by $V-I$ characteristics with the help of an ammeter, voltmeter, and load.

\section{Experimental Setup}

The experimental setup consists of a PV module along with a water flow circuit which includes a submersible pump, storage tank, and intermediate tank as shown in Figure 1(a). The solar PV module has a capacity of $25 \mathrm{~W}$ with dimensions $54 \mathrm{~cm} \times 47$ $\mathrm{cm}$. The storage tank is made up of a polymer with dimensions $33 \mathrm{~cm} \times 15 \mathrm{~cm} \times 10 \mathrm{~cm}$. The intermediate tank is fabricated using mild steel with a dimension of $44 \mathrm{~cm} \times 10 \mathrm{~cm} \times 10 \mathrm{~cm}$. An $18 \mathrm{~W}$ submersible pump is used to pump water from the storage tank to the intermediate tank. A butterfly valve is used in between the tanks for different mass flow rates.

The water from the storage tank is pumped to the intermediate tank using the submersible pump. Overflow water from the intermediate tank ensures the uniform flow on the top surface of the module. The water while flowing on the top surface recovers heat from the module. The mass flow rate of the water can be changed using a valve near the storage tank. Three different mass flow rates are considered for analysis. To measure the reduction in temperature, thermocouples are embedded in various places of the module as shown in Figure 1(b). A rheostat is used to vary the load to find out the electrical characteristics of the PV module. An ammeter and a voltmeter are used to determine the current in ampere and voltage in volts, respectively.

The thermocouple and temperature controller are used to measure the temperature of the module and water. The thermocouples are positioned in five different places around the module to measure the module temperature. An alcohol thermometer is used to measure the water temperature. The mass flow rate is measured by means of collecting a known volume beaker, and time is taken using a stopwatch. A sun meter is used to measure solar irradiance in $\mathrm{W} / \mathrm{m}^{2}$.

In order to find out the current and voltage characteristic of a solar PV module, the connections are made as per the connection diagram given in Figure 2. To determine various electrical parameters such as maximum power current, voltage, and power, a DC moving coil ammeter of range $0-10 \mathrm{~A}$ is used to measure the current flow and a voltmeter of range 0 $25 \mathrm{~V}$ is used to measure the voltage. After connecting the load to the PV module, values of voltage and current were taken for various resistance levels. $V-I$ characteristic was plotted to find the Maximum Power Point (MPP) of the solar module. The result obtained is used to plot the $V-I$ characteristic curve by which the output power can be calculated.

\section{Mathematical Model}

To simplify the mathematical calculations, the following assumptions have been made to develop approximate simulation models:

(i) The heat capacity of the PV module is neglected in comparison with that of water

(ii) The temperature effect on physical properties of each component is neglected

(iii) The temperature gradient of each layer exists only along the direction of water flow

(iv) The radiative heat transfer is neglected

(v) The energy transfer is in quasi-steady state

Applying energy balance equation for the glass cover,

$$
\alpha_{\mathrm{g}} I=U_{\mathrm{ge}}\left(T_{\mathrm{g}, 1}-T_{\infty}\right)+U_{\mathrm{ga}}\left(T_{\mathrm{g}, 1}-T_{\mathrm{w}}\right)
$$

The convective heat transfer coefficient between the glass cover and the environment is presented by Shan et al. [14],

$$
h_{\infty}=5.7+3.8 u_{\infty}
$$

where $u_{\infty}$ is the wind velocity on the upper surface of the PV panel. Therefore, the overall heat transfer coefficient between the glass cover and the environment can be described as

$$
U_{\text {ge }}=\left[\frac{\delta_{\mathrm{g}}}{\kappa_{\mathrm{g}}}+\frac{1}{h_{\infty}}\right]^{-1} .
$$

The overall heat transfer coefficient between the water flow and the glass cover can be described as

$$
U_{\mathrm{ga}}=\left[\frac{\delta_{\mathrm{g}}}{\kappa_{\mathrm{g}}}+\frac{1}{h_{\mathrm{w}}}\right]^{-1} .
$$

The convective heat transfer coefficient between the glass cover and water is $h_{w}$ is given by 


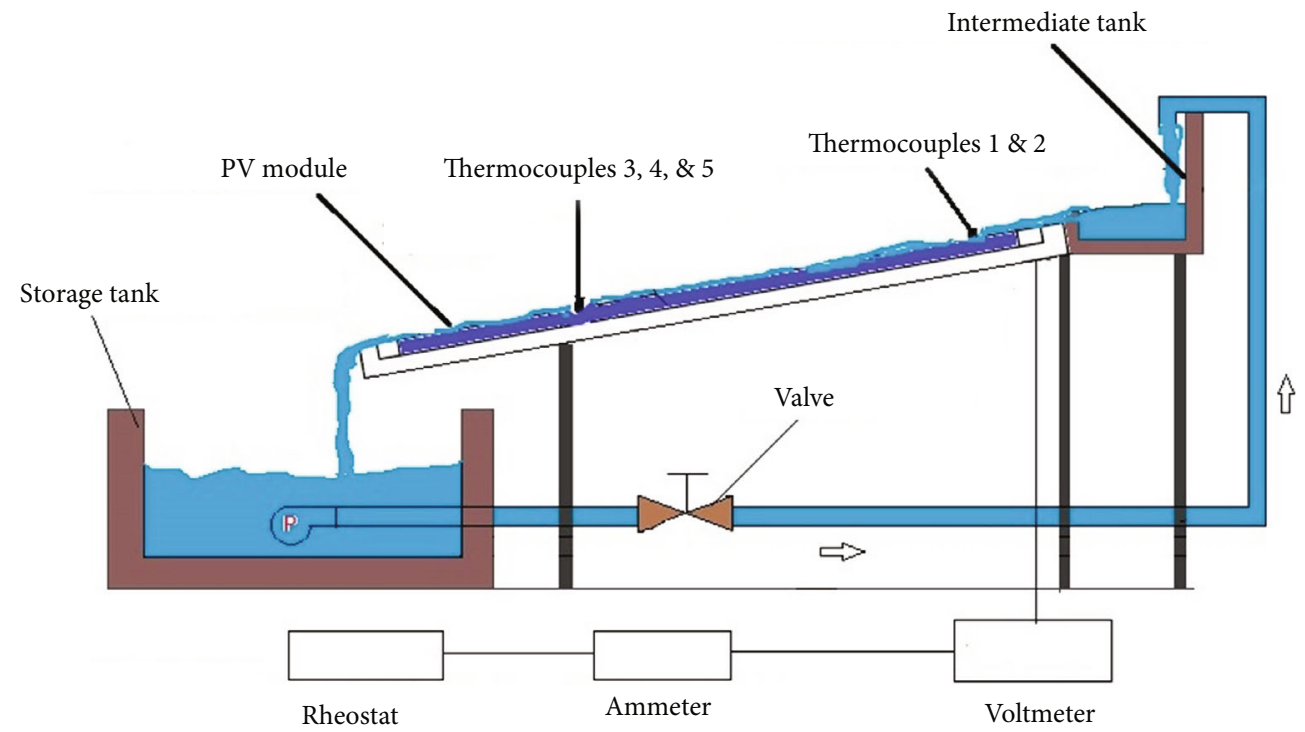

(a)

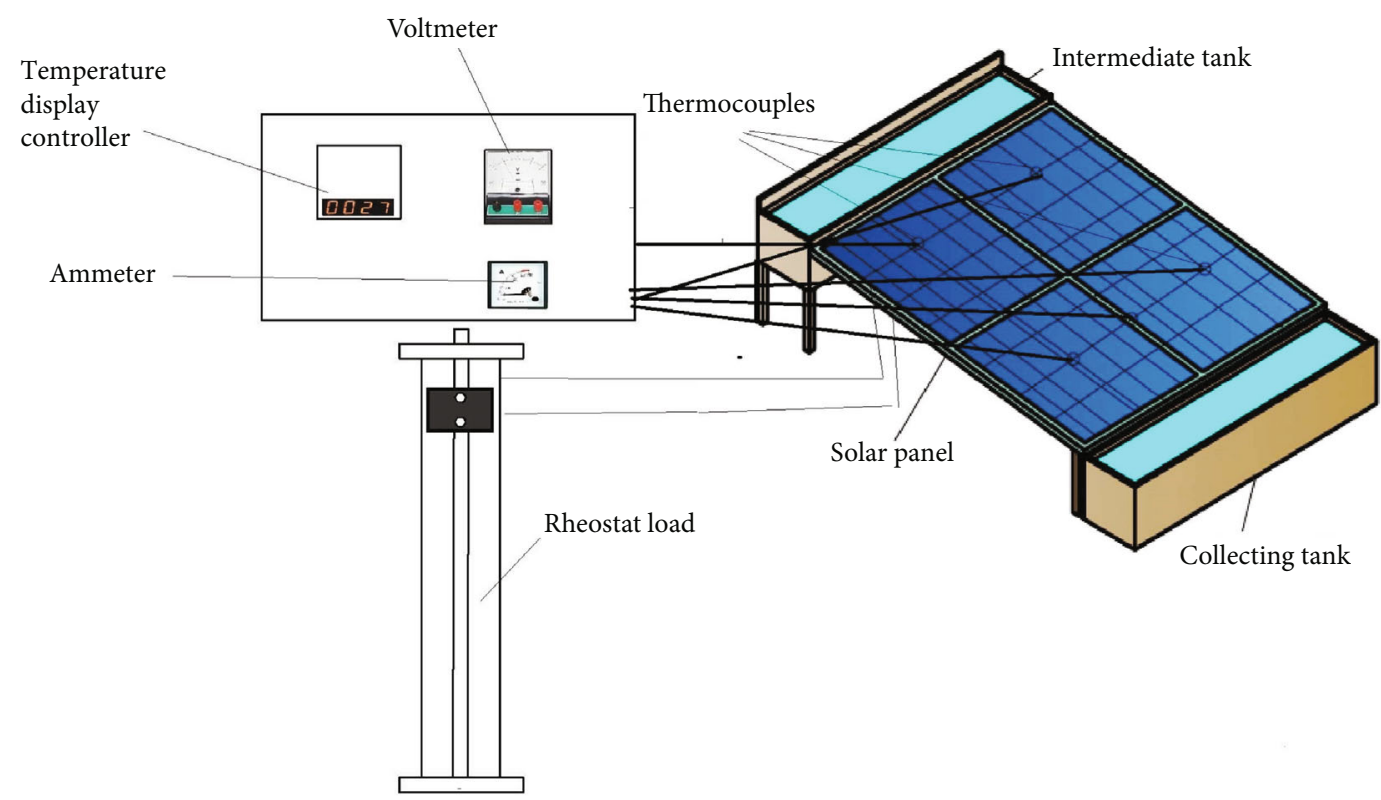

(b)

Figure 1: (a) Schematic diagram of experimental setup; (b) top view of the experimental setup.

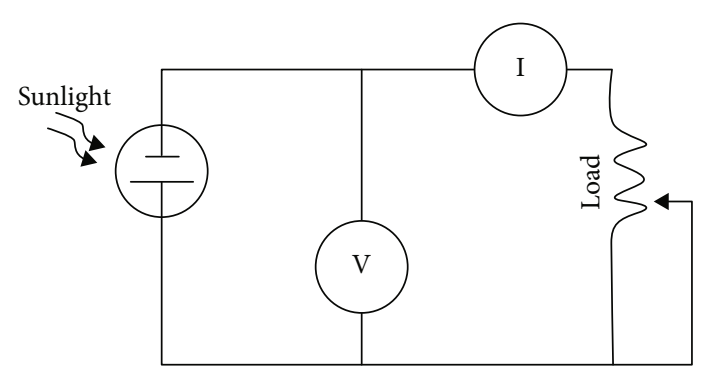

FIgURE 2: Electrical circuit for measuring $V-I$ characteristics.

$$
\begin{aligned}
& \mathrm{Nu}=\frac{h_{\mathrm{w}} L}{\kappa_{\mathrm{w}}}=0.664 \operatorname{Re}^{0.5} \operatorname{Pr}^{0.333}, \quad \text { if the flow is laminar, } \\
& \mathrm{Nu}=\frac{h_{\mathrm{w}} L}{\kappa_{\mathrm{w}}}=0.037 \operatorname{Re}^{0.8} \operatorname{Pr}^{0.33}, \quad \text { if the flow is turbulent. }
\end{aligned}
$$

The energy balance equation for water flow is

$$
\begin{aligned}
U_{\mathrm{ga}}\left(T_{\mathrm{g}, 1}-T_{\mathrm{w}}\right) \times W \times \delta x= & \dot{m}_{\mathrm{w}} C_{\mathrm{p}, \mathrm{w}}\left(\frac{d T_{\mathrm{w}}}{d x}\right) \delta x \\
& +U_{\mathrm{ga}}\left(T_{\mathrm{w}}-T_{\mathrm{g}, 2}\right) \times W \times \delta x .
\end{aligned}
$$


The linear equations are composed of Equations (1) and (6) with three unknown variables $\left(T_{\mathrm{g}, 1}, T_{\mathrm{g}, 2}, T_{\mathrm{w}}\right)$ which can be solved through the Gaussian elimination method.

\section{Data Reduction}

The efficiency of the solar photovoltaic module is denoted by $\eta$. It is determined by the ratio between the output power (VA) and the input power. The input power is the product of solar irradiance and area of the PV module.

(i) Output power, $P_{\mathrm{OUT}}=V_{\mathrm{OC}} \times A_{\mathrm{SC}}$ at $\mathrm{MPP}$

(ii) Input power, $P_{\mathrm{IN}}=I \times A$

(iii) Module efficiency, $\eta=P_{\mathrm{OUT}} / P_{\mathrm{IN}}$

$$
A=N \times A_{\text {Cell }} .
$$

\section{Error Analysis}

Table 1 represents the accuracy and uncertainty of the measuring devices used in this work. A thermocouple integrated with a temperature indicator is used as the temperature of the panel at different locations. The power input of the panel is measured using the voltmeter and ammeter. The mass flow rate is determined by means of collecting water in the beaker of known volume, and the time taken to fill the beaker is noted. Uncertainty in a measured value can be defined as chance of error occurred in the measured value of the instrument and it can be found using the following formula:

$$
\text { Uncertainty }=\frac{\text { Accuracy }}{\sqrt{3}} \text {. }
$$

\section{Results and Discussion}

Based on pipe diameter and valve opening, three different mass flow rates $(5.3,3.8$, and $2.3 \mathrm{~kg} / \mathrm{min})$ of cooling water flowing on the top of the solar PV module are used. Mass flow rate is fixed based on the valve opening. Efficiencies of the cooled PV module are compared with the PV module without cooling.

6.1. Uniform Cooling of PV Module. Five thermocouples are fixed along the flow surface on the PV module, and the temperature variation of all the five thermocouples during $9 \mathrm{am}$ to $3 \mathrm{pm}$ is plotted in Figure 3. It ensures that uniform temperature is maintained throughout the surface of the PV module. Uniform temperature drop throughout the PV module is maintained by means of uniform overflow of water on the PV module surface from the intermediate tank.

6.2. Thermal Characteristics. In order to examine the thermal performance of the solar PV module, module temperature values are taken at different operating conditions, namely, without cooling and with cooling at three different mass flow rates of $5.3 \mathrm{~kg} / \mathrm{min}, 3.8 \mathrm{~kg} / \mathrm{min}$, and $2.3 \mathrm{~kg} / \mathrm{min}$. Experiments are conducted in four different days with almost the same solar radiation variation as shown in Figure 4. The average
TABLE 1: Uncertainty of measuring instruments.

\begin{tabular}{lcccc}
\hline $\begin{array}{l}\text { SL. } \\
\text { no. }\end{array}$ & Instruments & Range & Accuracy & Uncertainty \\
\hline 1 & Temperature & $-10-$ & $\pm 1^{\circ} \mathrm{C}$ & $0.58^{\circ} \mathrm{C}$ \\
& indicator & $110^{\circ} \mathrm{C}$ & & \\
2 & Ammeter & $0-20 \mathrm{~A}$ & $\pm 1 \mathrm{~A}$ & $0.58 \mathrm{~A}$ \\
3 & Voltmeter & $0-300 \mathrm{~V}$ & $\pm 10 \mathrm{~V}$ & $5.77 \mathrm{~V}$ \\
4 & Measuring jar & $0-$ & $\pm 10 \mathrm{ml}$ & $5.8 \mathrm{ml}$ \\
5 & Stop watch & $0-99 \mathrm{hrs}$ & $0.01 \mathrm{~s}$ & $0.005 \mathrm{~s}$ \\
\hline
\end{tabular}

temperature obtained from five different locations is considered for this analysis. It has been noted that temperatures will be high in all time durations when the system is operating without cooling. As the surface is started cooling with uniform flow of water, the surface temperatures have been getting lowered suddenly. Increased mass flow rate shows better reduction in temperature. Augmentation of volumetric capacity during a higher mass flow rate causes the water to start to store the energy rather than conduction of the energy. This reduces the temperature of the module.

6.3. Electrical Characteristics. The effect of short circuit current on an open circuit voltage is depicted in Figure 5. There is a drop in $V_{\mathrm{OC}}$ without the cooling condition which is a result of increase in temperature. In the noncooled PV panel, the electric power output attains maximum at voltages reaching to $1.6 \mathrm{~V}$ whereas the specific point of this electric power output was shifted at voltages reaching to $1.7 \mathrm{~V}$ when cooling with a minimum mass flow rate of $23.3 \mathrm{~kg} / \mathrm{min}$. Increase in temperature increases the kinetic energy of electrons. This increases the short circuit current of the PV module which in turn reduces the open circuit voltage.

The decrease in the open circuit voltage reduces the output power and efficiency. That is exhibited in Figure 6. The curve for the noncooled PV module stands lower than that for the cooled PV module which suggests that cooling of the PV module affects the output power. The power output accelerated to a maximum of $21 \mathrm{~W}$ when cooling with a mass flow rate of $2.3 \mathrm{~kg} / \mathrm{min}, 22 \mathrm{~W}$ when the flow rate is set to $3.8 \mathrm{~kg} / \mathrm{min}$, and $23 \mathrm{~W}$ at the highest flow rate of $5.3 \mathrm{~kg} / \mathrm{min}$ whereas without cooling yields a maximum power of $19 \mathrm{~W}$ only. The cooled PV module has a maximum of $15 \%$ higher output power than the conventional PV modules while flowing water is at a mass flow rate of $5.3 \mathrm{~kg} / \mathrm{min}$.

The graph in Figure 7 compares the conversion efficiency of the PV module with and without cooling conditions. Results show that the cooling of the PV module increases efficiency and yields a minimum rise of $4 \%$ at the cooling rate of $2.3 \mathrm{~kg} / \mathrm{min}$ and a maximum of $14.3 \%$ at the flow rate of $5.3 \mathrm{~kg} / \mathrm{min}$. It shows good results in both thermal and electrical performances.

6.4. Comparison of Front Panel Cooling. Front panel cooling is carried out only with nozzle spray either by gravity or by pump force. No research work has been carried out in the 


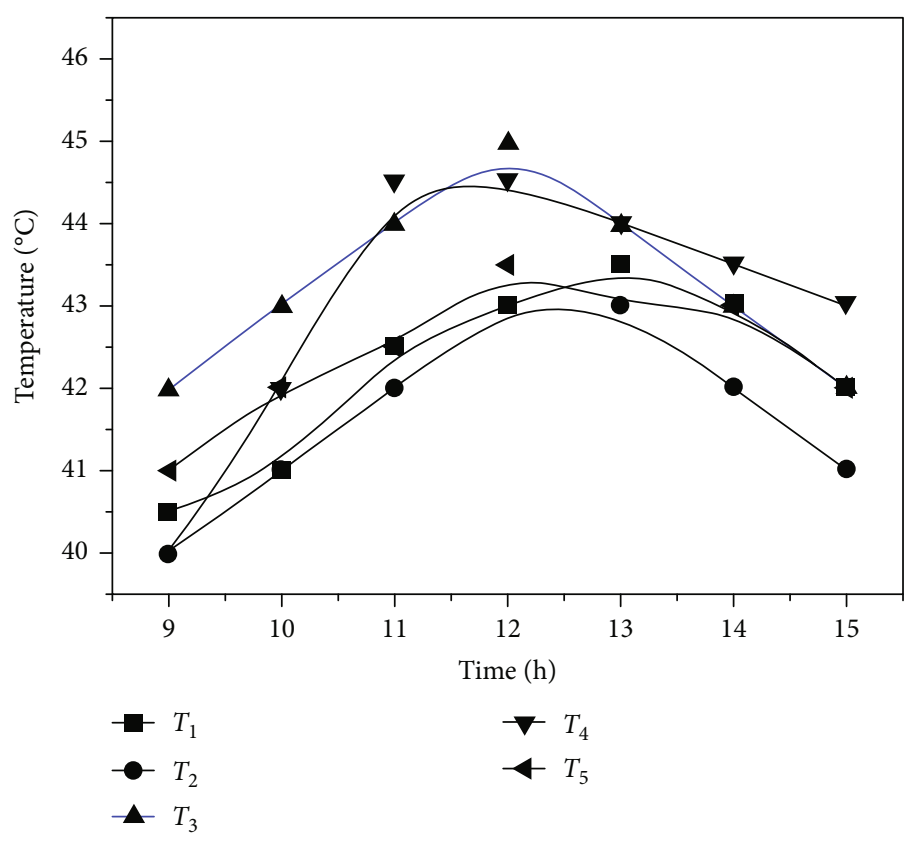

FIgURE 3: Evolution of module temperature.

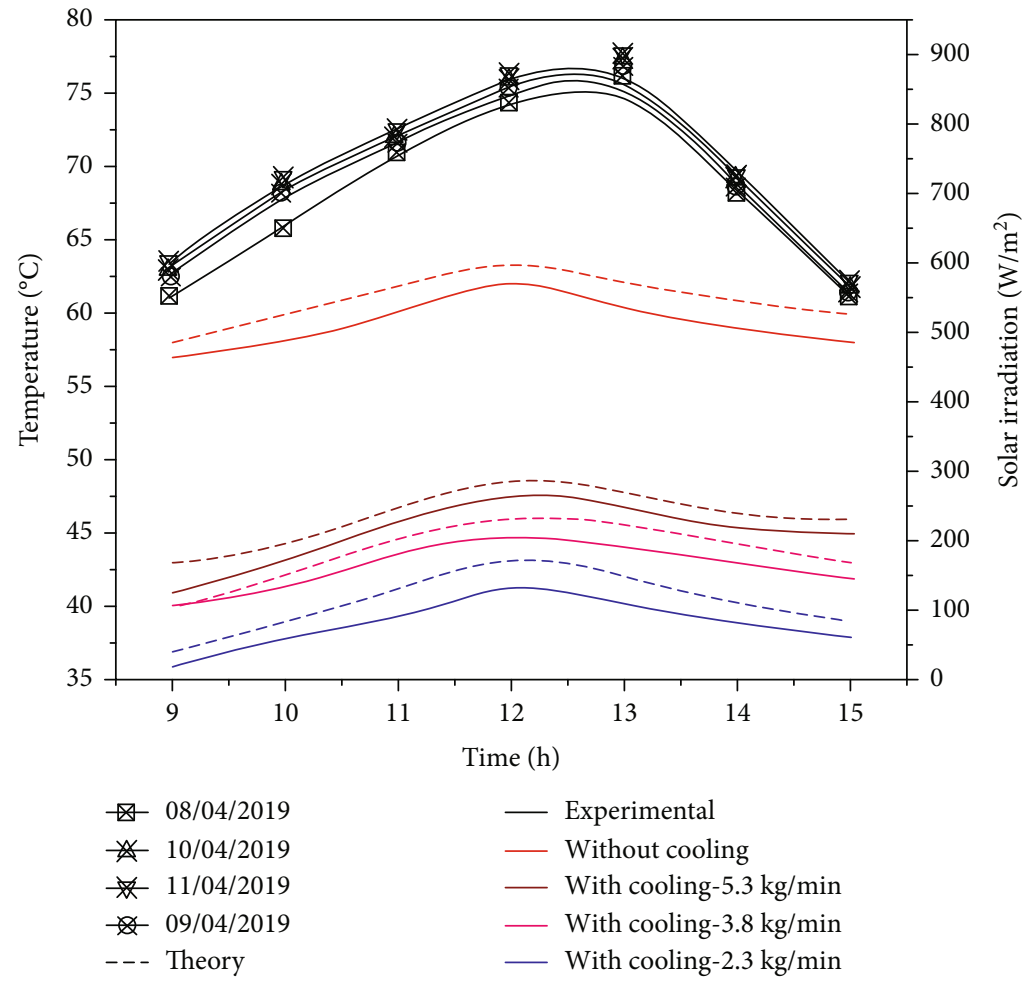

Figure 4: Temperature responses on different cooling rates.

way we conducted the experiment, i.e., use of an intermediate tank and overflowing the water at a specified flow rate. Hence, we could compare only the water spraying technique with the available data from the literature. The comparison is presented herewith in Figure 8.
Abdolzadeh and Ameri [11] obtained the maximum efficiency of $11.2 \%$ by water spraying through a nozzle at the rate of $0.2 \mathrm{LPS}$ for the panel maximum power of $45 \mathrm{~W}$. Nizetic et al. [13] obtained the maximum efficiency of $15.42 \%$ by water spraying through a nozzle at the rate of 


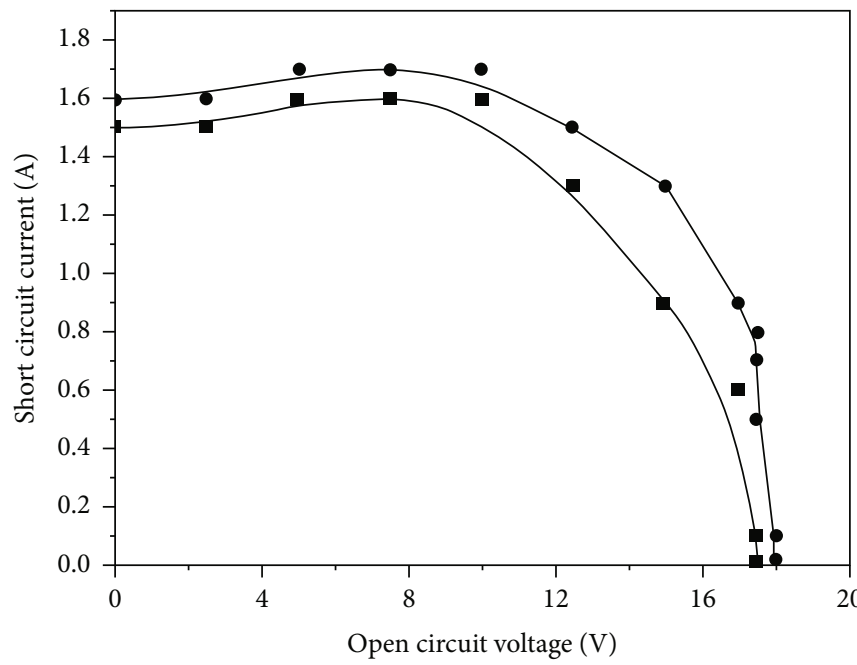

$\rightarrow$ Without cooling

$\rightarrow$ With cooling, $2.3 \mathrm{~kg} / \mathrm{min}$

Figure 5: $V-I$ characteristics.

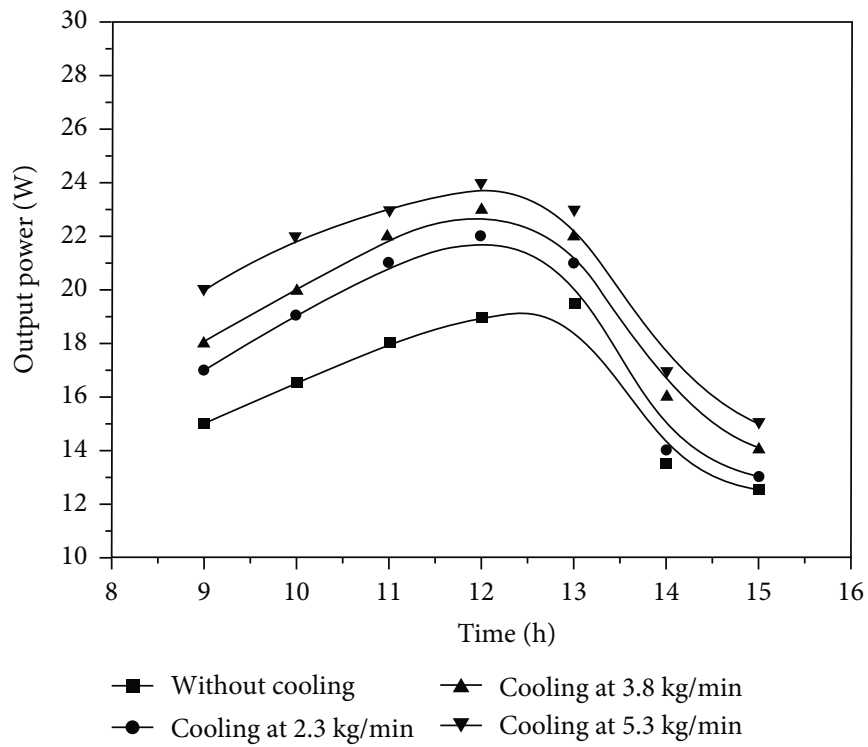

Figure 6: Output variation on cooling process.

0.04 LPS to 0.0625 LPS for the panel maximum power of $50 \mathrm{~W}$. In this current investigation for almost the same water flow rate, the efficiency obtained is $14 \%$ for $25 \mathrm{~W}$ panel which is relatively enhanced results comparing to the previous research work.

6.5. Cost Analysis. About $14 \%$ of the power output has been increased by means of uniform flow of water using the intermediate tank. To accomplish continuous flow, a submersible pump having $18 \mathrm{~W}$ power is used. The same $18 \mathrm{~W}$ power submersible pump is enough for a PV panel with a size of one square metre which has a standard power output of $200 \mathrm{~W}$. By considering the same $14 \%$ hike by uniform cooling, it is expected to increase the power output from $200 \mathrm{~W}$ to $228 \mathrm{~W}$. Considering the power of the submersible pump, the net power output has been increased by $10 \mathrm{~W}$. This value will be increased for a larger-sized PV module while using the same submersible pump.

\section{Conclusion}

The result shows that due to cooling, there is significant reduction in the loss of efficiency due to heating of the photovoltaic module. Cooling of the PV module increases the output power by $15 \%$ in comparison with the conventional PV module. Provision of uniform cooling enhanced the efficiency by $14 \%$ compared to the noncooled PV module. A higher mass flow rate of $5.3 \mathrm{~kg} / \mathrm{min}$ yields a maximum power of the PV module of $23 \mathrm{~W}$ while the maximum conventional PV module produced only a power of $19 \mathrm{~W}$. 


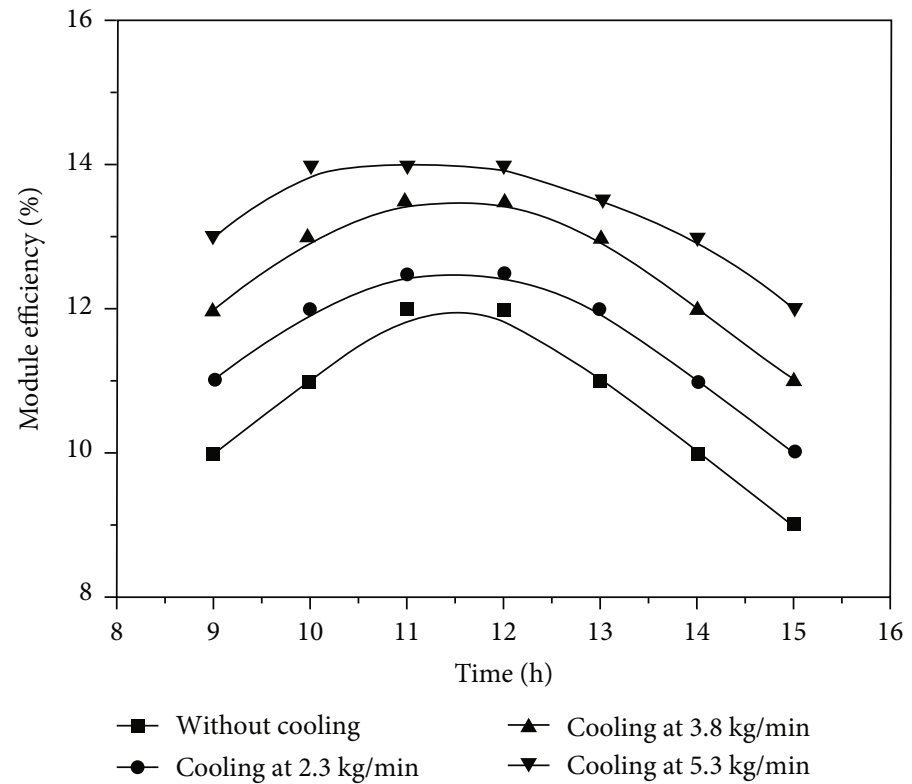

Figure 7: PV module efficiency.

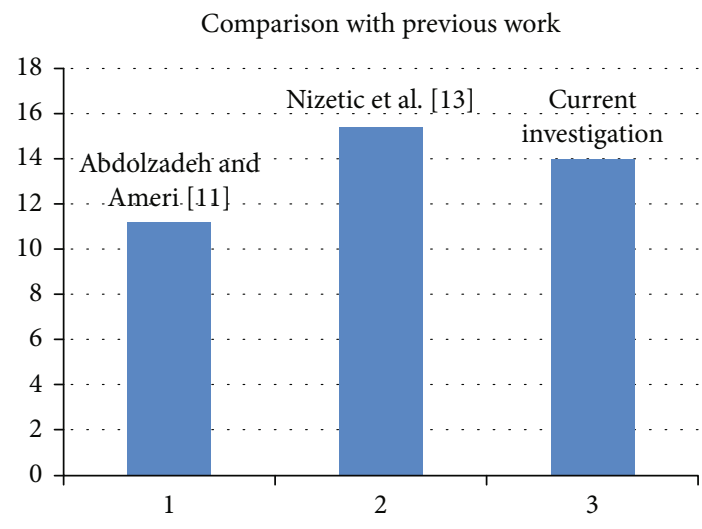

Maximum efficiency obtained (\%)

Figure 8: Comparison of front cooling panel.

Cooling of the PV module reduces the module temperature by $30 \%$. Modeling the temperature using the energy balance equation agrees well with the experimental value.

The direct benefit the experimental result is the reduction of the number of required cells for a particular power output with the beneficial side effect of visual appearance with a cleaner cell as the water is flowing over the module. The reduction in performance due to dust deposit can also be avoided. Cost analysis indicates that rise in net power output of $10 \mathrm{~W}$ is observed in a $1 \mathrm{~m}^{2}$ area of the PV module by considering the submersible pump. It is proposed to extend the research work by considering bottom cooling using the heat pipe technology along with top cover cooling by water.

\section{Nomenclature}

A: Current flow, area [ampere]

C: $\quad$ Specific heat capacity $[\mathrm{J} / \mathrm{kg} \mathrm{K}]$ $h$ : Convective heat transfer coefficient $\left[\mathrm{W} / \mathrm{m}^{2} \mathrm{~K}\right]$

I: $\quad$ Solar irradiation $\left[\mathrm{W} / \mathrm{m}^{2]}\right.$

$L$ : Flow length $[\mathrm{m}]$

$m$ : Mass flow rate $[\mathrm{kg} / \mathrm{s}]$

$N$ : Number of module

$\mathrm{Nu}$ : Nusselt number $=[h L / \kappa]$

$P$ : $\quad$ Power [W]

Pr: Prandtl number $=\left[\mu C_{p} / \kappa\right]$

Re: Reynolds number $=[u L / \gamma]$

T: $\quad$ Temperature [K]

$U: \quad$ Overall heat transfer coefficient $\left[\mathrm{W} / \mathrm{m}^{2} \mathrm{~K}\right]$

$u$ : Velocity $[\mathrm{m} / \mathrm{s}]$

W: Width $[\mathrm{kg}]$.

\section{Greek Letters}

$\alpha$ : Absorption coefficient

$\delta$ : Thickness [m]

$\kappa:$ Thermal conductivity $[\mathrm{W} / \mathrm{m} \mathrm{K}]$

$\infty$ : Ambient.

\section{Subscript}

Cell: Cell module

g: $\quad$ Glass cover

in: Input

out: Output

OC: Open circuit

SC: Solar cell

w: Water

1: Bottom glass temperature

2: $\quad$ Top glass temperature.

\section{Data Availability}

All the data supporting the conclusions of the study are presented as a graph in this paper. 


\section{Conflicts of Interest}

There are no conflicts existing in this work.

\section{Acknowledgments}

The authors would like to acknowledge with appreciation the Indian Society of Heating, Refrigeration and Air-conditioning Engineers (ISHRAE), India, and ISHRAE Madurai Chapter for the financial support for this analysis through the Research in ISHRAE Project Grant, and Thiagarajar College of Engineering, Madurai, India, for their tremendous support to successfully deliver this project.

\section{References}

[1] M. M. Rahman, M. Hasanuzzaman, and N. A. Rahim, "Effects of various parameters on PV-module power and efficiency," Energy Conversion and Management, vol. 103, pp. 348-358, 2015.

[2] H. Bahaidarah, A. Subhan, P. Gandhidasan, and S. Rehman, "Performance evaluation of a PV (photovoltaic) module by back surface water cooling for hot climatic conditions," Energy, vol. 59, pp. 445-453, 2013.

[3] M. Chandrasekhar, S. Suresh, T. Senthilkumar, and M. G. Karthikeyan, "Passive cooling of standalone flat PV module with cotton wick structures," Energy Conversion and Management, vol. 71, pp. 43-50, 2013.

[4] E. Chaniotakis, "Modelling and analysis of water-cooled photovoltaics," M.Sc. thesis, Faculty of Energy System and Environment, Department of Mechanical Engineering, University of Strathclyde, Glasgow, Scotland, 2001, http://www.esru .strath.ac.uk/Documents/MSc_2001/efstratios_chaniotakis .pdf.

[5] İ. Ceylan, A. E. Gürel, H. Demircan, and B. Aksu, "Cooling of a photovoltaic module with temperature controlled solar collector," Energy and Buildings, vol. 72, pp. 96-101, 2014.

[6] A. H. Alami, "Effects of evaporative cooling on efficiency of photovoltaic modules," Energy Conversion and Management, vol. 77, pp. 668-679, 2014.

[7] H. M. S. Bahaidarah, "Experimental performance evaluation and modeling of jet impingement cooling for thermal management of photovoltaics," Solar Energy, vol. 135, pp. 605-617, 2016.

[8] K. A. Moharram, M. S. Abd-Elhady, H. A. Kandil, and H. elSherif, "Enhancing the performance of photovoltaic panels by water cooling," Ain Shams Engineering Journal, vol. 4, no. 4, pp. 869-877, 2013.

[9] H. M. S. Bahaidarah, A. A. B. Baloch, and P. Gandhidasan, "Uniform cooling of photovoltaic panels: A review," Renewable and Sustainable Energy Reviews, vol. 57, pp. 1520-1544, 2016.

[10] R. Hosseini, N. Hosseini, and H. Khorasanizadeh, An experimental study of combining a photovoltaic system with a heating system, World Renewable Energy Congress, Sweden, 2011, http://www.ep.liu.se/ecp/057/vol11/040/ecp57vol11_040.pdf.

[11] M. Abdolzadeh and M. Ameri, "Improving the effectiveness of a photovoltaic water pumping system by spraying water over the front of photovoltaic cells," Renewable Energy, vol. 34, no. 1, pp. 91-96, 2009.
[12] F. Shan, F. Tang, L. Cao, and G. Fang, "Comparative simulation analyses on dynamic performances of photovoltaic- thermal solar collectors with different configurations," Energy Conversion and Management, vol. 87, pp. 778-786, 2014.

[13] S. Nizetic, D. Coko, A. Yadav, and F. Grubisic-Cabo, "Water spray cooling technique applied on a photovoltaic panel: The performance response," Energy Conversion and Management, vol. 108, pp. 287-296, 2016. 